\title{
HORIZONS ON CHRISTIANITY'S NEW DIALOGUE WTTH BUDDHISM
}

\author{
Paul F. Knitter \\ Xavier University
}

\begin{abstract}
A survey of recent Christian literature on the dialogue with Buddhisen reveels a conversetion which is new in both spirft and content. This article summarizes these new directions in five areas: (1) the methodology of dialogue; (2) the nature of the Ultimate and of religious language; (3) religious experience as an experience of selflessness; (4) the value and need of acting in the world, and (5) the unique, salvific mediation of Jesus and Gautama. In each of these areas, suggestions are offered as to how the new insights from the dialogue with Buddhism might aid in clarifying questions and incohorencies in present-day Christian doctrine and practice.
\end{abstract}

There is something different, something new in Christianity's dialogue with Buddhism over the past decade. Most of the works surveyed in this paper (see Bibliography) indicate a notable shift from the earlier "let's see the differences so we can establish the superiority" attitude to an approach which wants to take differences seriously, understand them correctly, in order to learn from them. The following pages will try to describe what this new attitude is discovering. After some preliminary considerations of the new attitude's methodology, I will highlight-much more is not possible-"converging insights" in four major areas of the Christian conversation with Buddhists. In each area I will also add my own reflections on how these new insights might be pursued in order to "correct" certain ambiguities in present-day Christian doctrine and practice.

\section{A Different Method for Dialogue}

Much to Learn and a Need to Learn It

While all of the works surveyed in this study evince a genuine respect for Buddhism and are a clear move beyond the "poor pagan" mentality, a few of the authors still stand on the same platform that sustained earlier, apologetic studies of Buddhism: they argue that Chris-

Paul F. Knitter received the Th.D. from Marburg University, West Germany and is presently Professor of Theology at Xavier University (Cincinnatti, OH 45207). His publications, most of which focus on the dialogue between Christianity and World Religions, include: Toward a Protestant Theology of the Religions (1974), and articles in Concilium (1980), The Journal of Ecumenical Studies (1975, 1979), Horizons (1978), and Neue Zeitschrift für systematische Theologie und Religionsphilosophie (1971, 1973). He is an Associate Editor of Horizons. 
tianity and Buddhism represent two totally opposed, absolutely unbridgeable religious views, or that the basic claims of Buddha, when compared to those of Christ, are radically inadequate (Callaway, Hossfeld, Aldwinckle). But these are the exceptions. The majority of the authors approach the conversation with Buddhists with a firm conviction that there is much for Christians to learn and, given the crisis of Western Christianity, an urgent need to learn it. A frequent image is that of "the covenant with the East": as the Fathers recognized a "covenant with the Greeks" from which Christianity could (and certainly did!) learn, today the same transformative encounter can take place with the East (Johnston, 1970, xiv; Gilkey, 2; Merton, 1975, 313).

For the conversation, however, to be fruitful, it must have as its starting point a deep commitment to Christ and to the truth discovered in him. Yet the depth of this commitment must be matched by the breadth of one's openness to the truth that may be contained in Buddha's message. Such openness is called for not only as an evident prerequisite for authentic dialogue but also as a demand of the Christian claim that God's love and revelatory presence are universal (Drummond, 207; Swearer, 49; Waldenfels, 206-07).

But in this dialogue, all the authors insist, the evident differences between Buddha and Christ must not be slighted; only if they are taken seriously can anything be learned. There are recurrent warnings against a facile syncretism which reduces all religions to a common denominator or against a simplistic arationalism which wants to cut away all doctrines in order to inhale a "common essence" (Merton, 1968, 43; Johnston, 1978, 43; Rupp, 3-26). Yet though it is admitted that these differences can sometimes make for "unbridgeable gaps," the common expectation of the authors is that it is especially at the points where Buddhism most differs that Christianity has most to learn. Drummond speaks of "converging foci" (206-07). This reflects a growing insight in the Christian conversation with Buddhism (and with other religions) that truth, especially religious truth, is not a matter of either-or but of both-and (Kreeft, 514-15; Spae, 1977, 3, 25; deSilva, xii-xiii). Every religious assertion must, somehow, be balanced by its opposite. One of the most recent and eloquent cases for this "both-and" quality of religious experience and doctrine is John A. T. Robinson's Truth is TwoEyed.

\section{The Experiential-Praxis Basis for Dialogue}

Another new insight into the method for dialoguing with Buddhism is the growing recognition that the partners must somehow "pass over," i.e., personally enter into the experience of the other religion. Dialogue must, to some extent at least, be based on a praxis of the other religion (J. Dunne, ix-xiii). This is particularly called for in the dialogue 
with Buddhism. To a great extent, Christians have misunderstood and therefore misused Buddhist language. Language, as found in Theravada and Mahayana texts and in Zen literature, is not meant primarily to provide "explanation" but "experience" (Merton, 1968, 36-38; Johnston, 1970, 173). "Buddhist terminology ... is largely phenomenological and descriptive and it aims to portray an experience rather than a reality. It is not metaphysical but soteriological, and if we interpret it ontologically, Buddhism appears atheistic, monistic, or pantheistic" (Gardini, 34-35).

Merton articulates a growing consensus when he suggests that therefore the conversation with Buddhists must first be a communion before it is a communication. It is a communion which originates in one's own religion and which is based on "the science of an ultimate experience." It enables Christians "to penetrate the ultimate ground of their beliefs" and allows them to touch the ultimate ground of Buddhist beliefs. Such communion, while it still recognizes "the very important essential differences" between Christianity and Buddhism, unveils the possibility that both "in their inner reality ... end up with the simplest and most baffling thing of all: direct confrontation with Absolute Being, Absolute Love, Absolute Mercy or Absolute Void ..." (Merton, 1968, 61-62; id., 1975, 310-12; Johnston, 1978, 77-78, 85-86; Swearer, 113-15; Dubarle, 71).

While this communion is "beyond the level of words," it can enable Christians to "find a common ground of verbal understanding" (Merton, $1975,315)$. Here we have a handle on the immense problem of language in the Christian-Buddhist conversation. Both traditions have developed in isolation from each other and therefore have "no common language." Yet with the experiential starting point of "communion" we can attempt a new method of dialogue: "... dialogue is that form of communication in which the means of communication has to be created in the course of the process of communication itself" (Sangharakshita, 58, also 59-63). We can perhaps discover that our "words," with all their baffling differences, are more complementary than contradictory. Merton therefore suggests, "the real area for investigation ... might after all be theology rather than psychology or asceticism." But he adds: "... it must be theology as experienced in Christian contemplation, not the speculative theology of textbooks and disputations" $(1968,58)$.

A further guideline in the new dialogue bears mention, even though it is not found as an explicit point of consensus among the authors. Swearer reminds us that the conversation can be bogged down with an overconcern for correct interpretation, for historical accuracy, for knowing whether the historical Buddha or the historical Jesus really said or meant this or that. Such questions, no doubt, are important. But they should not distract us from the fact that the dialogue is to be carried out 
between believers not between beliefs. It concerns not the ipsissima verba or the verissima facta of Buddha or Jesus but the way these two archetypal figures have been understood and followed throughout history and especially in our present day (Swearer, 16).

\section{God and God-Talk}

\section{Converging Insights}

1. Buddha was not an atheist: There is a clear consensus among most of the authors that to label Buddha an atheist or to declare that Nirvana or Sunyata are utterly godless is, as stated above, to abuse Buddha's language- or lack of language (deSilva, 67-74). Buddha is recognized as a religious practitioner who, as the parable of the poison arrow attests, wanted to resolve a practical problem not propose a new religious theory (Drummond, 73, 115); as Marx might put it, his primary concern was to transform the subject not to understand it. And because he realized that all words and theories are both inadequate and distractive, he refused to speak of God or Brahman/Atman. We should respect his silence, not fill it with our hasty interpretations (Johnston, 1970, 173; id., 1978, 107-12; Merton, 1968, 81; Spae, 1977, 19).

Yet many of the authors cautiously-sometimes not so cautiously - suggest that if we enter into the words that are used in the Buddhist scriptures and especially if we regard the practice of contemporary Buddhists, we will recognize that the Buddhist experience of Nirvana, Sunyata, Satori is not unrelated to the Christian experience of God (deSilva, 138-45). Drummond states that after considering "... the range of Buddha's teaching on Nirvana, I feel compelled to affirm that in some authentic way he was in contactwith aspects or dimensions of the Reality that Jesus terms the kingdom of God" (127). Dumoulin sees in Nirvana a genuine recognition of "Transcendence" (1974, 97-98). Johnston, witnessing the sense of participation, affirmation, and "pure dependence" experienced in Satori, holds that we are dealing with an experience ". . . upon which (for the Christian) it is impossible to put any name except that of God" $(1970,125)$. Buddhist Emptiness, therefore, is a "rich emptiness" (Johnston, 1970, 33), which may be a more accurate way of describing the Christian experience of the pleroma or fullness of God (Merton, 1968, 85; Panikkar, 1978). Sunyata, Vos suggests, can be translated "relativity," an attempt to describe the essential interrelatedness of all reality in a larger Whole (33). ${ }^{1}$ Whatever the propriety of such

\footnotetext{
${ }^{1}$ John Cobb, from his process perspective, diverges somewhat from the general direction of Christian interpretations of Sunyata. Comparing it with God, he speaks about "two absolutes" which complement each other. Sunyata expresses our essential interrelatedness, our unity in dependent co-origination (analogous to Whitehead's understanding of "Creativity"), while God is the guiding "principle of rightness" which "participates in every instance of dependent co-origination" (11-12).
} 
Christian interpretations, they express the willingness to affirm, and learn from, Buddhist experience and language of the Ultimate.

2. The immanence, non-duality, and suprapersonality of the Ultimate: While some authors express concern that Buddhist language often seems to dissolve any possible distinction between the Ultimate and the finite(Johnston, 1970, 41, 83-83; Fox, 10), the clear consensus is that to brand Buddhism as inescapably monistic is a rash judgment. ${ }^{2}$ The Buddhist challenges the Christian to embrace the logically more frustrating but personally more rewarding experience of the unity and diversity of the Ultimate and the finite, of Nirvana and Samsara. While Sunyata truly is every finite reality, while each particular entity truly is (and is not just "a piece of") Sunyata, still "particularity really exists"; Sunyata is what it is, the Absolute, in every particular, so that we have "an interpenetration of Absolutes" and still only one Absolute (Fox, 48-50; Dumoulin, 1979b, 102-14).

This is mind-boggling indeed and therefore an invitation to Christians to stretch their minds towards a fuller appreciation of the immanence of God. As modern theologians recently and mystics through the centuries have reminded us, Christians have missed this immanent God because of their unbalanced insistence on His Otherness and Transcendence (Johnston, 1970, 179). In Buddhism we can detect the immanent God of the Johannine writings which, in defining God as love, portray him not as a doer but as the doing (in us) of something, a God whose "reality ... is not to be sought beyond the phenomenal" (Bruns, 30-33, $46,89)$. Here is the God who cannot be localized, put in a place, either above the clouds or in our hearts (Johnston, 1971, 24). Here is a God truly encompassing, neither in us nor outside of us; but we and the world in Him (Kreeft, 521-22).

To experience, with the Buddhist, the immanence of the Absolute is to discover-or rediscover - that the relation between God and worldhumanity is not monistic (simple identity) or dualistic (clear distinction) but non-dualistic. A number of the authors suggest that any experience of God which has not yet felt this non-duality is incomplete or immature. The Cartesian "cogito," with its radical subject-object distinction, may be a profitable starting point for the natural sciences, but it constitutes a "false start" for our understanding of the Ultimate. Instead of beginning with distinctions, we can and should start with the original unity between the Ultimate and the finite-a unity which is available, Buddhists tell us, in a non-reflexive awareness which can best be described as "consciousness itself" or "pure consciousness" (Kreeft, 525; Merton,

\footnotetext{
${ }^{2}$ Again, Callaway strongly disagrees with this consensus; he is certain that Zen is nothing but "Idealistic Monism" (see 162-65; 232-33). In all the other areas of "converging insights" which are still to be considered in this study, Callaway stands in stark disagree-
ment.
} 
$1968,23-24)$. In this consciousness, which is given with our very being, God is known neither as an objective reality nor simply as a subjective experience. God is known to be radically beyond our distinctions between subject and object. Therefore, when Christians speak of God as an objective other, they must remind themselves that they are speaking only quoad nos and not quoad the reality of God; and when Buddhists maintain that the Absolute is our subjective consciousness, they too must be reminded that they are speaking adverbally not adjectivally, i.e., they are describing how they experience the Absolute, not what the Absolute is (Kreeft, 525). A true religious experience is the experience of God being subjective in us; it is to touch the "Single Center of all beings," the "still point of the turning world," the ipsum esse subsisting in us and we in it; it is an experience in which it is impossible neatly to locate our selves or the Self of God. The Ultimate and the finite, then, are not "one"; yet neither are they "two"; they make up a non-dual Reality in which both are and have their being in each other (Kreeft, 526-27; Merton, 1968, 9-13, 23-24, 71-73).

But does such a conversation with Buddhism still allow for a personal God? Reservations are voiced that the Buddhist perception of the non-duality between the Ultimate and the finite, while establishing a splendid vision of unity, easily renders meaningless any talk of personal community among humans or with God (Fox, 180-83). Yet there are converging insights among the authors that the experience of Nirvana is not utterly devoid of personal qualities. Drummond finds a basis for this in the frequent references in Buddhist texts to Nirvana or the Dharma as "the Loverly" $(124,193)$. C. Dunner and Merton go further. They claim that the Buddhist experience of Enlightenment is not contradictory to but can include the experience of "Being (which) has fallen in love with beings" so that a "secret name" of Being might well be "Father" (C. Dunne, 51-56, 39-41). Buddhist praxis indicates that to realize Nirvana as Absolute Reality is to experience it as "Absolute Love": "Pure Being is Infinite Compassion ... Absolute Emptiness is Absolute Compassion" (Merton, 1968, 84-87; Johnston, 1978, 67-68).

The majority of the authors, however, want to qualify such personal language. They accept the Buddhist admonition that much of Christianity's personal theism has limited and "offended" the Ultimate. God understood as Thou, for all its merits, has led to an anthropomorphized Deity, a totally-Other, who controls our lives or who can be used by humans to control their fellows. Buddhists therefore underscore the reminder of Ratzinger that "the personal dimension of God infinitely transcends human personhood, so that the concept of person, as much as it is illuminating, still proves to be an inadequate similitude" (in Dumoulin, 1974, 168). Our authors clumsily search for a more adequate language: God is personal but not a personality (Bruns, 45); God is 
"pre-personal" (Dumoulin, 1974, 164), an "unpersonal personal" (Waldenfels, 181-82), "supra-personal." Better to admit that personal language of God is essentially inadequate, that God is both personal and impersonal (Robinson, 13-40). Only when one has felt and recognized this non-dual, more than personal quality of the Ultimate, can one fittingly address it as Thou (Lassalle, 68).

3. The Non-Being of God: Gilkey describes his reaction when, for the first time, a Buddhist (Masao Abe) asked him why Christian theology begins with being rather than nonbeing. It "blew my mind," he admits; and it led him to suggest that this focus on divine nonbeing might more deeply and coherently reveal the Christian God than has traditional "being-centered" Western theology (Gilkey, 2-3; Spae, 1979, 39-40; Johnston, 1978, 115-25). God's reality and activity transcend and therefore include both being and nonbeing. Christian theologians have missed this. "God is being qualified dialectically and yet essentially by nonbeing, and so his mystery transcends the categories of both being and nonbeing. It is in this dialectical pattern ... that he manifests himself in all his works; and it is on this pattern alone that the self can find itself-by losing itself" (Gilkey, 10). Creation is possible only if God's being is "emptied," i.e., limited by nonbeing (Dumoulin, 1974, 180-82; id., 1979b, 144-53; Gilkey, 10-11; Waldenfels, 191-93). This transcending dialectic is contained even more clearly in the deepest implications of the Christian understanding of incarnation and the cross in which Deity realizes itself in "letting-go," in embracing Nothingness (Swearer, 109-11). Reality, God's and ours, unfolds only in this constant movement into and embrace of what is not Itself (Waldenfels, 178, 197-207; Gilkey, 11).

\section{A Corrective for Christian Doctrinalism and Dualism}

1. One of the aspects in Christian consciousness, both past and present, which stands in urgent need of a "Buddhist balance" is what might be termed "doctrinalism." Simply stated: Christianity seems to have taken its words and concepts, whether biblical or papal, much too seriously. This obsessive insistence on right words or doctrines (orthodoxy) blurs the fact that all religion originates from a deeply personal experience and not from an affirmation of propositions (Merton, 1968, $39-41,56)$. Orthodoxy provides a clear and distinct concept of God which too easily becomes Freud's transcendent crutch for our insecurity and anxiety (Fernando, 1979, 93). And the security of right knowing debilitates so readily the primacy of right acting.

Our Buddhist brothers and sisters remind us of what our mystics all along and our theologians in their better moments have admitted: that to experience and to know God is to encounter das Geheimnis 
schlechthin-absolute mystery! This is mystery which, as much as we are grasped by it and dare to speak of it, will always remain beyond our words and dogmas. Theology, therefore, if it is to be true to its task, must ultimately and always be a reductio in mysterium (Waldenfels, 186-89). And Christians, while they must "cling to God," need not and ought not to "cling to views and ideas about God" (Johnston, 1970, 190; Lassalle, 79-93).

Yet Christians will remind their Buddhist partners that words/doctrines are important, even necessary. In stressing the emptiness of words and the limitations of the intellect, Buddhists run the risk of not being able to "say anything about anything" (Johnston, 1970, 92; id., 1978, 43; Waldenfels, 159-76). If Christianity is the Body of Christ and the People of God, it needs some kind of a "common language" (Merton, 1968, 47). And because it claims the incarnational immanence of God in the world, it will not look on the forms or symbols of God in the world as meaningless illusions; while the faceless mystery of God cannot be contained in any one human face, it can be reflected in many faces (C. Dunne, 75-82). But in making such affirmations, Christians remain in need of the balance of Buddhist negation: as much as Christians affirm their words and doctrines, they must be ready to negate them; they can proclaim the value and even necessity of doctrine only if with equal insistence they recognize its inadequacy. Buddha might use a paradox here: words about God can be valid and useful only if they flow from a profound experience of silence. Behind and within all Christian doctrine there must be "... a silence which prepares the way for the word and the silence which is the word's highest utterance" [C. Dunne, 23; Panikkar, 1971, 84-89; Steindl-Rast, 175-79).

2. The Christian encounter with Buddha's understanding of the Ultimate can also be, I suggest, an invaluable aid in addressing another area of incoherence in Christian proclamation: dualism. Christianity, to be sure, proclaims itself as a "this-worldly" religion. More than any other of the world religions, it claims that it is best able to affirm and guide the "basic faith" of secularity in the ultimate value of this world and human involvement in it. And indeed, the central symbols of Christianity-kingdom, incarnation, resurrection-are this-worldly and non-dualistic in that they affirm a God intimately involved in history and working with human action. Yet despite the non-dualistic content of these symbols, despite the rallying calls of theologians to affirm this world, many Christians-and this includes theologians-remain "anonymous dualists." The reason for this is that they continue to interpret their non-dualistic symbols in a basically dualistic philosophical framework-usually traced back to Neo-Platonism.

Dualism, sometimes anonymously and sometimes quite consciously, infects and debilitates Christian affirmation of the humanum 
and mundanum (Rupp, 38, 69). How can the dualistic "God of theism" be truly immanent in history when He is perfect unto himself, in need of no other, immutable and related to the world rationis tantum? How can life in this world truly prepare for and be part of the future Kingdom when, as even many theologians of hope insist, that Kingdom will arrive as an other-worldly "coming," not as a this-worldly "becoming," a "mighty act of God" carried out not because of but despite the actions of humans. The eternal significance of human action is thus jeopardized by the sovereignty of God's grace; at the most, human activity is meaningful only as an "admission ticket" to or a "proleptic sign" of another divine order. ${ }^{3}$ How can we take the "supernatural existential," the non-dual relation of nature and grace seriously when, in the final analysis ("double gratuity!" nothing in us or in God requires the bestowal of grace?

Many Christian thinkers, liberation and especially process theologians, are attempting to root out this prevailing Christian dualism. Some of the converging insights in the new dialogue with Buddhists can be of vital help in enabling them to coherently explain what the symbols of incarnation and resurrection really imply. The Buddhist experience of the supra-personal immanence of the Absolute in the finite can confirm and perhaps refine the process notion of panentheism: God will not be seen so much as a Super-Being relating to finite beings but as the unitive Mystery which lives and moves and has its being within finite beings, as they have their being in It. And the paradoxical non-duality which Mahayana Buddhism claims to be the relation between Nirvana and Samsara will enable the Rahnerians to carry through with their notion of the supernatural existential and admit that "nature" cannot be without "grace," nor "grace" without "nature." A non-dualistic notion of God-world will also lend coherence to the claims of the liberation theologians, for if God is subjective in us, he cannot carry out his liberating action without us (nor we without him) so that our actions are his and the Kingdom we build here on earth is His Reality. The new conversation with Buddhism, then, would seem to enable Christians to become more fully and actively aware of the Non-Duality which is inherent, but often blurred, in the Christian vision.

\section{The Selfless Self}

\section{Converging Insights}

1. A Misunderstanding: The consensus of authors examined for this study are in basic agreement with Merton's assessment that most

\footnotetext{
${ }^{3}$ For a further unveiling of the dualism that hides behind the eschatology of theologians of hope like Moltmann and Pannenberg, see: Langdon Gilkey, Reaping the Whirlwind (New York: Seabury, 1976), pp. 226-38; Jose Miguez Bonino, Doing Theology in a Revolutionary Situation (Philadelphia: Fortress, 1975), pp. 138-50.
} 
Christian discussions about the Buddhist view of Anatta/No-self have been, like the discussions about Nirvana, "completely equivocal" (Merton, 1968, 118; Swearer, 75; Drummond, 138-40). Again, the blame can be pinned on an abuse of Buddhist language. In his talk about being a No-self, Buddha was not proposing a metaphysical doctrine but an ethical invitation; he was not arguing an "eternalist" or an "annihilationist" concept of the soul but urging a radically different way of experiencing ourselves and the selves ofothers (Swearer, 179-80; deSilva, 30-32). The problem is that Christians have understood that language much too literally; or they have taken their own language about the "new self" or about the "self in Christ" so literally and simplistically that they are blind to the possible complementarity between the No-Self and the New Self (Merton, 1968, 118). In fact, some would argue that Anatta is a via negationis and the New-self a via affirmationis, both trying to draw us, along quite different paths, to the same amazing discovery: that the human self can be so transformed, in consciousness and in way of acting, that it no longer resembles the self it thought it was. It is so new as not to be the original self (C. Dunne, 65-67; Swearer, 80; Drummond, 142, 147; Merton, 1968, 76-77; Kreeft, 520).

2. The Meaning of Anatta: Recognizing past misunderstandings of Anatta, our authors move on, in surprising agreement, to try to grasp what the Buddhist No-self really implies. They recognize that Buddhism provides Christians with an opportunity to know and experience that the true reality of the person does not consist in being an individuum, a given entity; rather, the true self is radically, essentially, constantly in relation to other selves and to all reality; its "being" is constantly one of ongoing "dependent co-origination"; its being is relating. Therefore, the true self is a selfless self, constantly losing-finding its self in its relations with others (deSilva, 90-103; C. Dunne, 16-17). Many of the authors use the psychology of Jung to explain and confirm this. It is possible to break through our ego-consciousness and experience a consciousness in which there is no ego, in which we are aware of ourselves-at-one with reality around us, vitally related (Johnston, 1970, 54; Drummond, 14648, 195; Merton, 1968, 64; Franck, 77). In T. S. Eliot's terms, "you are the music" (Johnston, 1970, 23). According to Aquinas, intellectus est quodamodo omnia-our selves, in a sense, are all things (Johnston, 1968, 55).

3. The Self-in-God: Converging insights among our authors point out that the Buddhist Anatta doctrine can aid Christians in more fully appropriating the content of such expressions as to be "in Christ," "united with God," "a temple of the Spirit," or of the text (cited by almost all the authors), "I live, not yet I, but Christ lives in me" (Gal. 
2:20). Having "passed over" to Buddha's experience of Anatta, Christians can realize that such language means more than an ethical imitation of Christ, more than being filled with God as a glass might be filled with water. Rather, Buddhists suggest that these Christian claims are inviting us to a non-dual experience of Christ/God (Swearer, 82-83; Merton, 1968, 118-20; Johnston, 1970, 75-76; Drummond, 151-52). It is an experience in which we become aware of the claim of the mystics that "the soul is God" (Johnston, 1970, 75); or, phrased more cautiously, "... that God is (among other things) my true identity" (Kreeft, 521). In arriving at the depths of our consciousness we discover that there is no self-consciousness; rather, we are conscious of ourselves with the consciousness of God; we truly participate "in the mind of Christ" (Phil. $2,5)$. This experience is not only one of immense peace in that it affirms the value of our divine being; but also, in it we find ourselves operating out of a new principium, a new center which is no longer the selfconcerned, ratiocinating ego. We no longer find ourselves "obeying" God's law, but simply being and carrying out our true identity: a No-self at one with God and others (Swearer, 82-83; Franck, 134).

4. The Fall: A number of the authors find that the Buddhist understanding of Anatta provides needed clarification for the Christian notion of Sin and the Fall. In the light of our true nature as No-selves, our sinfulness is not seen as a corruption of human nature due to some past event; "original sin" is not an ontological separation from God. Rather, the root cause and essence of our sinfulness is ignorance-the pseudoknowledge acquired from eating of the Tree of Knowledge which leads us to think that we are individuals and that the purpose of existence is to maintain and augment that individuality (Franck, 97). Sin stems from a false self-consciousness which makes the self aware of what is good or evil for itself (Merton, 1968, 127). The Fall, therefore, is the prevailing disposition of humans-fostered through generations of collective bad karma - "to treat the ego as objects of desire or of repulsion" (Merton, 1968, 82-83; Fox, 60; Drummond, 101-02; Dumoulin, 1979a, 22-26).

\section{A Corrective for Christian Individualism}

Perhaps the most valuable lesson which Christianity can learn from these converging insights concerning the Anatta-doctrine is to recognize the individualism which has infected the church's all too Western interpretation of the Gospel. In our present state of world affairs, this lesson appears more urgent than ever. The undialectical affirmation of the self and of being which animates so much of Western politics, economics, philosophy, and theology, "may be," in Gilkey's words, "the principle of world destruction" (8). The inability to see the value of non-being and of the No-self, the insistence that the welfare and growth 
of the individual self or the national self cannot be jeopardized has led to the domination and exploitation of other selves and of nature, making earth an endangered planet. How much has the church bought into and even fostered this insidious sacrality of the self? The new conversation with Buddhism is suggesting to Christians that they will not be able to make a meaningful contribution to "a new world order" unless they and their theologians (even process theologians!) rid themselves of the vestiges of Western Substantialist and existentialist philosophy and its overemphasis on the ultimate value and inviolability of the individual.

It must be stressed that to learn from the Buddhist No-self is not simply a matter of Christians affirming more clearly what they already know. It will lead to a radical revision of Christian attitudes. It will help bring about what John Cobb feels is a much needed "postpersonal form of Christian existence, in which Western Christianity is finally able to free itself from its attachment to individualized personal existence as a final good" and in which "interpersonal (and international) relations can be understood in a different way."4

It is only this post-personal form of Christian existence, which understands the True Self as the Selfless Self, that will enable Christianity, together with Buddhism, to further the "quantum leap" which humanity today must make if its evolution is to continue: the evolutionary leap from individuality to communality, from a world of divided, warring tribes to a "global village" (Franck, 86-87). Only if human beings cease understanding themselves as individuals, only if they profoundly realize that to be themselves they must be part of othersonly then will they be able to form authentic community, whether in the church or among nations; only then will they be able to get beyond the patriotism and nationalism that continue to hamstring efforts for global community (deSilva, 146-59; Fox, 71).

\section{Value of This World and of Action in It}

Converging Insights

1. Buddhism not world-denying: While many of the authors recognize the potential for Buddhism, especially when understood monistorically, to be a "cop-out" on history (Rupp, 51, 54; Dhavamony, 53), they voice a practically unanimous opinion that Buddhism is not essentially a world-denying religion. To judge it so is to fall prey to Western scholars' all too simplistic dichotomy between the mystical, passive religions of the East and the prophetic, active religions of the West (Johnston, 1978, 10). Many authors call for recognition of the fact that today Buddhism is just as intent and just as successful as is Christianity in adjusting to the world-affirming faith of contemporary men and

'Christ in a Pluralistic Age (Philadelphia: Westminster, 1975), pp. 220, 212. 
women (Dumoulin, 1974, 150-58; id., 1979a, 29; Spae, 1977, 22). In doing this, Buddhism is returning (like Christianity) to its early sources and proving its "original universal character" which is "essentially humanistic" (Dumoulin, 1974, 61; id., 1979b, 84-87).

The authors agree that from what we can know of the original message of Gautama, the First Noble Truth does not imply a condemnation of the finite world and life in it. Rather, the First Truth reveals that, since all finite reality is in constant "dependent co-origination," everything is a "no-thing" and must not be made absolute. To make anything in the world ultimate and to hold on to it with all one's being is to grasp at an ultimately disappointing idol (Drummond, 186-88; Swearer, 62-68; Kreeft, 527). Realizing this, one can "sit loose in the saddle" as one moves on to an active involvement in the world (Drummond, 107-09). Therefore Buddha, like Jesus proposed a revolutionarily new view of society without being a social reformer. While he could accept the favors of kings and rajas, Gautama demonstrated a dangerous "freedom from any concept of the sacral king" (Drummond, 198). And even though he did not call for the abolition of the caste system (as Paul did not reject Slavery), his Anatta doctrine and his acceptance of all men (and later women) into the Sangha constituted "a radical rejection of both principle and practice of caste" (Drummond, 198, 48, 63-67; Rupp, 64-68). Drummond argues that many, if not all, of the world-denying attitudes found in Theravada literature do not stem from the Buddha but are most likely "the result of later developments in Buddhist monastic communities"; he compares such attitudes with similar world-denying developments in early Christianity, even in St. Paul (Drummond, 150, 100).

2. Are history and evil real? It is not easy to focus a clear consensus among the authors concerning their interpretations of Buddhism's response to this question. As we have seen, Gautama's original message and especially its Mahayanist interpretation contain a recognition of the need to act in the world. But many of our authors point out that it is difficult for Buddhists to coherently ground this need to act in a recognition that time and process are real, that there is the genuine possibility of things going wrong and that therefore it is necessary to counteract evil and work for a better world (Rupp, 50-52; Merton, 1968, 132; Robinson, 94). There is, then, a general recognition among the authors that in these areas of the dialogue, Buddhists perhaps have much to learn from Christians (Spae, 1977, 23).

But the warning is voiced that it is too simplistic to brand the Buddhist experience of time as cyclic. Given the central Buddhist affirmation that bad karma can be overcome and that there is a process of rebirths, one might better speak of an upward spiral movement or time within Samsara (Spae, 1977, 4; Dumoulin, 1979b, 119-24). But more 
importantly, it is recognized that the Buddhist insistence that the fullness of Reality is to be experienced in the Now is not totally opposed to the Christian insistence on history. In fact, the Buddhist Now is a needed balance for Christianity's exaggerated concern with the historical which tends to place "salvation" primarily in a fact of the past and leads to a fundamentalistic "absolutizing [of] the relativities of history" (Robinson, 54-55). Also, Christianity's preoccupation with the future tends to blur the fact that while Jesus proclaimed the Kingdom to come, he also, paradoxically, announced that it is now (Merton, 1968, 138).

Concerning the reality of evil, many of the authors remind us that it is again an abuse of Buddhist language simply to conclude that if evil is described as an "illusion" it is therefore not real. For Buddhism, there is no dualistic distinction between the subjective and the objective orders, between the ordo cognoscendi and the ordo essendi. Therefore, "... a change (or a lack) in consciousness is also a change (or lack) in the real" (Rupp, 38). This is corroborated if we take seriously Socrates' and Newman's equation between true knowledge and true virtue; what we truly know (Newman's "real assent") or do not know really affects and is what we are or are not (Kreeft, 528). If all this is then understood within the framework of the Buddhist experience of Reality-as-Now, we can happily recognize that while we must strain all efforts to overcome the present real evil of ignorance, ultimately all evil and all ignorance is not real; every instance of evil is a "felix culpa" (Kreeft, 535). In Buddhist terms, all ignorance is contained and overcome in the fullness and the dynamic interrelatedness of Nirvana; in complementary Christian terms, all evil can and will be an occasion for good and for greater unity, i.e., an occasion by which the Kingdom-to-be is realized as the Kingdom-now. Ultimately, evil is an illusion. "Death, where is thy sting?" (1 Cor. 15:55).

3. The natural need to act in the world: These converging insights as to the "illusion" of history and evil are confirmed by further insights among our authors concerning the Buddhist (especially Mahayanist) non-dual distinction between prajna/bodhi (wisdom) and Karuna (compassion). To be swept away by wisdom into the quiet see of Sunyata is also to be swept up into the dynamic stream of compassion for all beings. It is impossible truly to be wise without actively being compassionate. Some of the authors mention the frequent Christian claim that karuna is not the same as agape since it does not really admit of any "other" to love; but they go on to point out that while this may be true in theory, there is no difference between the Buddhist practice of compassion and the Christian practice of charity. Evidently, such theory is missing something (Dumoulin, 1974, 119-20; Kreeft, 534). As to the further Christian claim that karuna aims at bringing others to enlightenment, 
while agape is intent on changing both the person and society, Fox responds that compassion "will do whatever it must to awaken men to wisdom"; and that includes the relief of poverty, the abolition of oppression, the establishment of a just social-political order (62-66). For the Buddhist, the fundamental motivation for such efforts towards social change is not the intrinsic superiority of one social-economic order over another but the desire that all men and women experience enlightenment and know the relativity of all individuals and theories. Fox, however, adds that in regard to the relative adequacy of any one social system, Buddhism shows a greater affinity for socialism than for capitalism (74-79).

\section{A Corrective for Christian Activism}

Thanks to liberation/political theologians, Christians today are becoming more aware that Christian life in the recent past has been excessively a matter of "individual piety," that today they are called to act in the world, that liberating praxis is of the essence of the Gospel. In order to carry out this urgent program of liberation and to avoid certain excesses of their own, liberation theologians can learn much from the new dialogue with Buddhism. Their Buddhist brothers and sisters offer them two crucially important insights into why praxis so easily becomes activism, or, why there can be no effective liberation without spirituality.

First, the new conversation with Buddhism, as described in this section, tells the liberation theologian that it is not sufficient that liberation praxis be based on careful social analysis and on a concrete political program; it must also be grounded in the individual's contemplative or mystical experience of his/her and the world's nondual relation with God. Praxis must be fruitfully wedded not only to theoria but also to sophia. Base Communities must foster not only a social "raising of consciousness" (concienciamento) but also a mystical "deepening of consciousness." Buddhists would offer a number of reasons for this.

- Only if our praxis is rooted in and sustained by the profound nirvanic realization that our actions are God's, that they are not just our feeble efforts but part of a larger, indefatigable divine process-only then will we truly know what we are doing; only then will we continue doing it in face of the crucifying opposition that all social liberation confronts. Without such mystical grounding, our acts become activism: isolated, scattered, frantic, mindless (Merton, 1975, 349).

- Also, while Buddhists will learn from the liberation theologian that sin is systemic, part of social structures, they will also remind the liberationist that the root problem is not social structures but human consciousness. Yes, sin does infect the body politic, and the body may be so infected that immediate, even revolutionary surgery is needed. Yet 
the Buddhist warns that the infecting bacteria is human ignorance, a false consciousness which, because it believes in individual egos, creates a false picture of society. Only if this bacteria, this false consciousness is destroyed can social structures truly be changed.

- Buddhism therefore clarifies both the means and the ultimate goal of liberation praxis. The final end of all social involvement is not to fashion a new social order or to dethrone multinational tyrants or to remove poverty and hunger (although these certainly are immediate and urgent ends); rather, the principal goal of liberation is to bring all men and women to personal enlightenment, to a mystical experience of their No-selves and essential interrelatedness in the Kingdom. Such enlightenment must also be considered part of the necessary means to the ultimate end. If it is not, the immediate achievements of social change and dethronement of tyrants will be short-lived.

Second, the new conversation with Buddhism tells liberation theologians that if their praxis is not to become activism, it must not only be grounded in contemplation; it must also be detached from its own action. The Buddhist insistence on detachment and the Christian insistence on involvement must paradoxically and creatively include each other. "... [T] he mystical centre needs the prophetic centre if it is not to become airborne. ... But equally the prophetic centre needs the mystical centre if it is not to become arrogant, narrow and unlovely ..." (Robinson, 64-65). If we are not truly detached from our praxis we all too easily consider our action the only way to effect change; we are inclined to crush anyone in its way; or we ourselves are crushed when our actions do not yield their intended fruits. To be truly free for action and involvement we must be free from it. And this freedom is the fruit of the mystical experience by which we know that our feeble actions are part of a larger liberation-process, and that while in the moment they are necessary, in an ultimate sense, they are not. We can act without seeking the fruits of our actions. The mystical experience of our nonduality with God/Kingdom embues us with "the double capacity to be fully and effectively invested in what one takes to be morally required activity; and yet also to be able to stand back and laugh at oneself" (Rupp, 83). It equips a person with "the freedom from concern that goes with being simply what he is and accepting things as they are in order to work with them as he can" (Merton, 1968, 31). The Buddhist insistence on detachment, then, enables liberation theologians to appropriate, in their praxis, the full implications of the traditional Christian doctrine that we are liberated "by grace" and not by our works in themselves; it enables them to grasp the freedom-from-and-for acting contained in the Gospel images of being like the birds of the air and the lilies of the field, of not being overconcerned with what we shall eat or wear in order to seek first the Kingdom of God in the assurance that then all will be added and liberation will take place. 


\section{Jesus and Buddha: Mutually Unique}

\section{Converging Insights}

1. Similar missions: The authors who explicitly take up a comparison of the "persons and works" of Jesus and Buddha do so, for the most part, with caution (Drummond, Amore, C. Dunne, Williams, Hossfeld, Dhavamony, Aldwinckle). ${ }^{5}$ They avoid facile generalizations about Jesus and Buddha being two faces of the same God or about one identical message in two different languages. Yet these authors do recognize certain basic similarities in the missions of the Christ and the Buddha.

The missions of both consisted basically in revealing something and in modeling what was revealed. Buddha, like Jesus, was recognized as an authoritative teacher. Both were seen to be preaching an urgently important message (the Dharma, the Gospel); and both were acclaimed as "speaking with authority"- the authority that comes from having an extraordinary experience of what they were talking about (Nirvana, the Father) (Drummond, 182-84; Dhavamony, 83-87). Also, both were claimed to embody, to model the full reality of their revelation. Thus, Buddha was called "he who has arrived" (Tathagata) and Jesus, "he who is to come." Or more simply, both were experienced as "Master" or "Lord" who carried out their exalted roles not by domineering but by showing the way (Dhavamony, 50-52; Nhat Hanh in Berrigan, 107). And from what we can cautiously know of the self-awareness of both Masters, it seems that Buddha, like Jesus, was animated with a sense of universal mission; all peoples must hear the message. Such an awareness of personal mission, according to Drummond, "has no parallel in the previous history of India" (44, also 80$)$.

As to the content of what was revealed and modeled, the previous three sections of this study indicate the common consensus among our authors that the messages of Buddha and Jesus concerning the Ultimate, the Self, and the World are clearly different but that the differences are ultimately much more complementary than contradictory. Amore crystallizes this complementarity, which he calls "One Message," in Jesus' doctrine of "the Pure Mind" found especially in the Gospels of Luke and Matthew; the One Message is that of orthopraxis, i.e., the same ethical vision (58-95). Williams agrees and throughout his book argues that the hub of Jesus' message is the same radical call to destroy the ego and to live in interrelating love as is found in Buddha's message (see esp. 27-35; 48-74). C. Dunne, for all her concern to face squarely the differences between Jesus and Buddha, summarizes the attitude of many of our authors: " . . . from a Christian perspective, I see Gotama as a precursor,

\footnotetext{
5Jay Williams in his Yeshua Buddha stands as somewhat of an exception to this statement. His book presents a thoroughgoing retelling of Jesus' message from the perspective of Mahayana Buddhism.
} 
preparing the way of the Lord. From a Buddhist perspective, I see Jesus as a true successor of the Buddha" (10). ${ }^{6}$

2. Similar glorification myths: Few of the authors explicitly consider the processes by which Jesus and Gautama were further understood and "glorified" after their deaths. Dhavamony rules out the validity of any such comparison (52-53). J. Dunne and especially Amore would disagree. Dunne makes the theological claim that we can recognize a genuine incarnation of God in all humans (x, 94-95). Amore, arguing phenomenologically, shows that especially in the Mahayanist school there developed "the nearly complete deification of the Buddha"; this process "had a considerable impact on the earlier, more conservative Buddhist sects as well" (51). Intrinsic to this interpretation is what Amore terms "an ancient, legendary pattern" of descent--the Ultimate descends to humanity to become part of it. Both Christianity and Buddhism are, according to Amore, incarnational religions. He points out that while there were forms of Docetism in Buddhism as in early Christianity, their overriding affirmation is, expressed in Christian terms, that God is "embodied" $(16,57)$. Elsewhere I have argued more extensively that both Jesus and Buddha were experienced and interpreted according to similar glorification-incarnation myths. ${ }^{7}$

\section{A Corrective for Christological Exclusivism}

What has been suggested so far in this section, as well as in this entire study, compels Christians to take a new and more critical look at the exclusivism that has marked their understanding of the uniqueness of Jesus. The new context of religious pluralism, exemplified sharply in the new dialogue with Buddhism, forces new questions which urge new answers concerning Jesus as "One Mediator" (Robinson, 121). If the incarnation and divinity of Jesus can be understood in terms of Enlightenment, i.e., the personal realization and living of divine-human nonduality, if Gautama seems to have experienced just such an Enlightenment, if the Buddhists are on to something when they claim that we should expect "other Buddhas"- then Christians must ask whether their traditional claims that Jesus is exclusively unique or even inclusively unique (e.g., in the "anonymous Christianity" model) are accu-

${ }^{6}$ While Aldwinckle admits clear similarities in the missions of Jesus and Buddha as well as in the manner in which they were interpreted and "divinized" after their deaths (see 211-26), he holds to a definite opposition between their messages. Following the more traditional Christian interpretation of Buddhism, he argues that Buddha's Gospel contradicts that of Jesus in three key areas: Buddhe could admit of no personal Transcendent, he denied the reality of the self, he preached an essentially other-worldly doctrine (22735). 665-68.

"Jesus-Buddha-Krishna: Still Present?" Journal of Ecumenical Studies 16 (1979), 
rate. This is not to deny the uniqueness of Jesus, but it inquires whether we have misunderstood it and the New Testament language about it. ${ }^{8}$ Robinson uses a distinction which poses the question incisively: "From being totus Christus and totus Deus, the one who is utterly expressive of Godhead, through and through, so that in him there is no unChristlikeness at all, he becomes totum Christi, totum Dei, the exhaustive revelation and all sufficient act, so that apart from him there is nothing of God and no Christlikeness at all" (104). To be totus Deus, must Jesus be totum Dei?

In the dialogue with Buddhism, Christians can recognize the possibility that both Jesus and Buddha are mutually unique. Both preserve their distinctive difference and importance. And in a sense, both can be said to remain absolute in that they present their followers with a salvific revelation or Dharma which calls for total commitment and which is claimed to be meaningful for all peoples of all times. But this will be an absoluteness which is not defined by its ability to exclude or include other revelations; rather, Jesus and Buddha will be proven absolute insofar as they are able to relate to each other's truths, include and be included by each other. Christians, then, can continue to be totally committed to Jesus the Christ and to claim that for them God has decisively been revealed in him; but they will also feel not only the possibility but the need to "clarify, complete and correct" (Robinson, 125) their understanding of Jesus and of God through dialogue with Buddhism as well as with other religions. ${ }^{9}$

This study has tried to show that the new Christian conversation with Buddhists is just such a "clarifying, completing and correcting" dialogue. In understanding better their Buddhist brothers and sisters, Christians have the opportunity to understand better that their God is beyond all words and truly immanent in the world, that they themselves are radically social beings able to transform society only if they mystically realize this, and that their Savior is a Christ who defines God but does not confine Him.

\footnotetext{
- For further indications that New Testament language about Christ does not require an exclusivistic understanding of his uniqueness, see P. Knitter, "World Religions and the Finality of Christ: A Critique of Hans Kung's On Being a Christian," Horizons 5 (1978), 153-56.

'I have tried to show how such an understanding of Jesus' uniqueness can ground a unitive pluralism of religious experience in "Christianity as Religion: A Roman Catholic Perspective," in What is Religion? An Enquiry for Christian Theology (Concilium, vol. 136), ed. David Tracy and Mircea Eliade (New York: Seabury, 1980), pp. 16-19.
} 


\section{Bibliography}

Aldwinckle, Russel F.

1976 "Jesus or Gotama?" in More Than Man: A Study in Christology (Grand Rapids: Eerdmans], pp. 211-46.

Amore, Roy C.

1978 Two Masters, One Message: The Lives and Teachings of Gautama and Jesus (Nashville: Abingdon).

Berrigan, Daniel and Hanh, Thich Nhat

1975 The Raft Is Not the Shore: Conversations Towards a Buddhist Christian Awareness (Boston: Beacon).

Bruns, J. Edgar

1971 The Christian Buddhism of St. John (New York: Paulist).

Callaway, Tucker

1976 Zen Way, Jesus Way (Rutland, VT: C. E. Tuttle).

Cobb, John B., Jr.

1977 "Buddhist Emptiness and the Christian God," Journal of the American Academy of Religion, Vol. 45, pp. 11-25.

Dhavamony, Mariasusai

1979 "The Buddha as Saviour," in Christianity and Buddhism, M. Dhavamony and C. Geffre, eds., Concilium, Vol. 116 (New York: Seabury), pp. 43-54.

Drummond, Richard $\mathrm{H}$.

1974 Gautama the Buddha: An Essay in Religious Understanding (Grand Rapids, Eerdmans).

Dubarle, Dominique

1979 "Buddhist Spirituality and the Christian Understanding of God," in Christianity and Buddhism, pp. 64-73.

Dumoulin, Heinrich

1974 Christianity Meets Buddhism (LaSalle, IL: Open Court).

1979a "Buddhism-A Religion of Liberation," in Christianity and Buddhism, pp. 22-30.

1979b Zen Enlightenment: Origins and Meaning (New York: Weatherhill).

Dunne, Carrin

1975 Buddha and Jesus: Conversations (Springfield: Templegate).

Dunne, John

1972 The Way of All the Earth (New York: Macmillan).

Fernando, Mervyn

1972 "Self, Reality and Salvation in Christianity and Buddhism," International Philosophical Quarterly, Vol. 12, pp. 415-25.

1979 "The Buddhist Challenge to Christianity," in Christianity and Buddhism, pp. 88-96.

Fox, D. A.

1975 Buddhism, Christianity and the Future of Man (Philadelphia: Westminster).

Franck, Frederick

1974 Pilgrimage to Now/here (Maryknoll: Orbis).

Gardini, Walter

1976 "Critical Points of the Buddhist-Christian Dialogue," Japanese Religions, Vol. 9, July, pp. 33-47.

Gilkey, Langdon

1978 "The Mystery of Being and Nonbeing: An Experimental Project," Journal of Religion, Vol. 58, pp. 1-12. 
Griffiths, Bede

1977 Return to the Center (Springfield, IL: Templegate).

Hossfeld, Paul

1974 "Jesus (der Christus) und Siddhartha Gautama (der Buddha)," Theologie und Glaube, Vol. 64, pp. 366-89.

Johnston, William

1970 The Still Point: Reflections on Zen and Christian Mysticism (New York: Harper \& Row).

1971 Christian Zen (New York: Harper \& Row).

1978 The Inner Eye of Love: Mysticism and Religion (New York: Harper \& Row).

Kreeft, Peter

1971 "Zen Buddhism and Christianity: An Experiment in Comparative Religion," Journal of Ecumenical Studies, Vol. 8, pp. 513-38.

Lassalle, H. M. Enomiya

1974 Zen Meditation for Christians (LaSalle, IL: Open Court).

MacCormick, Chalmers

1972 "The Zen Catholicism of Thomas Merton," Journal of Ecumenical Studies, Vol. 9, pp. 802-17.

Merton, Thomas

1968 Zen and the Birds of Appetite (New York: New Directions).

1975 The Asian Journal of Thomas Merton (New York: New Directions).

Panikkar, Raimundo

1971 "Nirvana and the Awareness of the Absolute," in The God Experience, J. P. Whelen, ed. (New York: Newman), pp. 81-99.

1978 "Sunyata and Pleroma: The Buddhist and Christian Response to the Human Predicament," in The Intra-Religious Dialogue (New York: Paulist), pp. 77-100.

Robinson, John A. T.

1979 Truth Is Two-Eyed (London: SCM Press).

Rupp, George

1979 Beyond Existentialism and Zen: Religion in a Pluralistic World (New York: Oxford University Press).

Sangharakshita, Maha Sthavira

1979 "Dialogue between Buddhism and Christianity," in Christianity and Buddhism, pp. 55-63.

deSilva, Lynn A.

1978 The Problem of the Self in Buddhism and Christianity (New York:

Spae, Joseph Barnes \& Noble/Harper).

1977 The Buddhist-Christian Encounter, Pro Mundi Vita Bulletin, JulyAugust, Vol. 67.

1979 East Challenges West: Towards a Convergence of Spiritualities (Chicago: Chicago Institute of Theology and Culture).

Steindl-Rast, David

1972 "Christian Confrontation with Buddhism and Hinduism," Monastic Studies, Vol. 8, pp. 171-87.

Swearer, Donald K.

1977 Dialogue: The Key to Understanding Other Religions (Philadelphia:

Vos, Frits Westminster).

1979 "The Discovery of the Special Nature of Buddha: Sudden Enlightenment in Zen," in Christianity and Buddhism, pp. 31-39. 
Waldenfels, Hans

1976 Absolutes nichts: Zur Grundlegung des Dialogs zwischen Buddhism und Christentum (Basel-Freiburg: Herder).

Williams, Jay $\mathrm{G}$.

1978 Yeshua Buddha: An Interpretation of New Testament Theology as a Meaningful Myth (Wheaton, IL: Theosophical Publishing House). 